THE serum concentration of two pro-angiogenic cytokines: basic fibroblast growth factor (bFGF) and transforming growth factor beta1 (TGF-ß1), and antiangiogenic factor endostatin in the serum of 80 never treated B-cell chronic lymphocytic leukemia (CLL) patients and 27 healthy volunteers was measured using an enzyme linked immunosorbent assay. The serum levels of both bFGF and TGF- $\beta 1$ were found to be significantly higher in the CLL group (median 40.5 $\mathrm{pg} / \mathrm{ml}$ and $38.6 \mathrm{ng} / \mathrm{ml}$ respectively) when compared to the control group (median $9.4 \mathrm{pg} / \mathrm{ml}$ and $18.9 \mathrm{ng}$ / $\mathrm{ml}$, respectively) $(p<0.001)$. The levels of endostatin were not significantly different in CLL and control groups (median $12.3 \mathrm{ng} / \mathrm{ml}$ and $8.4 \mathrm{ng} / \mathrm{ml}$, respectively) $(p=0.09)$. In the group of CLL patients the level of bFGF was significantly higher in patients with progressive disease as compared with patients with stable disease (median $90.5 \mathrm{pg} / \mathrm{ml}$ and $40.5 \mathrm{pg} / \mathrm{ml}$ respectively) $(p<0.001)$. Patients in Rai stage III and IV also had significantly higher levels of bFGF than patients in Rai stage $0-$ II (median $100.1 \mathrm{pg} / \mathrm{ml}$ and $29.3 \mathrm{pg} / \mathrm{ml}$ respectively) $(p<0.001)$. The levels of both TGF- $\beta 1$ and endostatin were lower in patients in Rai stage III and IV (median $28.9 \mathrm{ng} / \mathrm{ml}$ and $9.1 \mathrm{ng} / \mathrm{ml}$ respectively) than in patients in Rai stage $0-$ II $(42.8$ $\mathrm{ng} / \mathrm{ml}$ and $13.1 \mathrm{ng} / \mathrm{ml}$ respectively $)(p<0.001$ and $p=0.002$ respectively). The level of endostatin was also lower in the group of CLL patients with progressive disease (median $10.0 \mathrm{ng} / \mathrm{ml}$ ) as compared to patients with stable disease (median $20.5 \mathrm{ng} / \mathrm{ml})(p=$ 0.008 ). In conclusion, the disturbance in the balance between pro- and anti-angiogenic factors may have an important influence on the course of CLL.

Key words: Angiogenesis, bFGF, TGF 1 , Endostatin, Chronic lymphocytic leukemia

\section{Circulating proangiogenic cytokines and angiogenesis inhibitor endostatin in untreated patients with chronic lymphocytic leukemia}

\author{
Joanna Gora-Tybor, Jerzy Z. Blonski and \\ Tadeusz Robak ${ }^{\text {CA }}$
}

Department of Hematology, Medical University of Lódz, ul Pabianicka 62, 93-513 Lódz, Poland

\author{
${ }^{\mathrm{CA}}$ Corresponding author \\ Tel: + 48426895191 \\ Fax: + 48426895192 \\ E-mail: robaktad@csk.am.lodz.pl
}

\section{Introduction}

Angiogenesis is a multi-step process involving endothelial cell proliferation, differentiation, migration and organisation to form tubules. It has been well established that angiogenesis is involved in the expansion and dissemination of primary solid tumors. Many studies have demonstrated an association between microvessel density and prognosis in different cancers. ${ }^{1}$ Angiogenesis is regulated by many substances with pro-angiogenic activity and a number of inhibitors. Basic fibroblast growth factor (bFGF) and transforming growth factor beta (TGF $\beta 1$ ) are potent inducers of angiogenesis, enhancing the proliferation of epithelial cells and fibroblasts and are involved in the regulation of cellular replication and synthesis of many components of the extracellular matrix. ${ }^{2}$ Endostatin is a recent discovered, a $20 \mathrm{kDa}$ fragment of the C-terminal, noncollagenous domain of collagen XVIII with antiangiogenic activity. It is able to block mitogen-activated protein kinase activation in endothelial cells and specifically inhibits endothelial proliferation. ${ }^{3}$

Recent studies indicate that angiogenesis may also play an important role in the pathogenesis of hematological malignancies, including lymphoma, myeloma and leukemia. ${ }^{4-6}$ Evidence of the role of this process in chronic lymphocytic leukemia (CLL) originates from the finding that increased vessel density was observed in the bone marrow of CLL patients. ${ }^{7}$ There are also studies that have revealed that CLL B cells spontaneously secrete a variety of pro and anti-angiogenic factors including vascular endothelial growth factor (VEGF), TGF $\beta 1$, bFGF and endostatin. ${ }^{8-11}$ The shift in balance between production of anti-angiogenic factors and pro-angiogenic factors is a process that may have significant influence on disease progression.

The aim of our study was to compare the serum levels of the pro-angiogenic factors: bFGF and TGF $\beta 1$ and the anti-angiogenic factor endostatin, between healthy blood donors and a group of never treated 
CLL patients. We have also investigated if the levels of pro- and anti-angiogenic factors correlate with the stage of the disease.

\section{Patients and methods}

\section{Patients}

The study involved 80 B-CLL patients and 27 healthy volunteers. All CLL patients fulfilled the National Cancer Institute-Sponsored Working Group diagnostic criteria for CLL. ${ }^{12}$ There were 48 male patients and 32 female patients with a mean age of 64 years (range 40-78). Forty-four patients had stable disease and 36 had progressive disease (including lymphocytosis doubling time $<1$ year, massive splenomegaly, bulky adenopathy, recurrent disease-related infections, weight loss $>10 \%$ in a 6-month period, temperature of $38^{\circ} \mathrm{C}$ related to disease, extreme fatigue, III and IV Rai stage disease). ${ }^{13}$ According to Rai classification ${ }^{14} 18$ patients were in 0 stage, 15 in I, 19 in II, 6 in III and 22 in IV stage of the disease. Fiftytwo patients (Rai 0-II) were included in good prognosis group and 28 (Rai II-IV) in bad prognosis group. ${ }^{15}$ All patients included in this study were previously untreated. Characteristics of the patients are shown in Table 1.

An assessment of history and a physical examination was performed as initial diagnostic procedure. The laboratory tests included: complete blood count, immunoglobulins level, liver and renal function tests, bone marrow aspiration for morphology and immunophenotyping. Surface marker analysis was performed to confirm B-cell origin and monoclonal proliferation, including immunoglobulins heavyand light-chains, CD5, CD10, CD19, CD20 and CD23.

The controls included 18 men and 9 women, with a mean age of 52 years (range 40-75).

This project was performed in accordance with the Helsinki Declaration. Informed consent was obtained

Table 1. Patient characteristics

\begin{tabular}{ll}
\hline Number of patients & 80 \\
\hline Age & \\
Median & 64 \\
Range & $40-78$ \\
Sex (male/female) & $48 / 32$ \\
Rai stage & \\
0 & 18 \\
I & 15 \\
II & 19 \\
III & 6 \\
IV & 22 \\
Stable disease & 44 \\
Progressive disease & 37 \\
Disease duration (months) & \\
Median & 52 \\
Range & $3-100$ \\
\hline
\end{tabular}

from all patients participating in the study. The local Ethics Committee approved the project.

\section{Serum sampling and cytokine determination}

The serum obtained was stored at $-80^{\circ} \mathrm{C}$ until assayed for cytokines. The cytokines serum concentrations were assayed by specific, commercially available, enzyme linked assay kits. The kits for bFGF and TGF $\beta 1$ were the products of R\&D Systems Inc. (Minneapolis, MN, USA) and the endostatin was a product of Oncogene Research Products (Boston, MA, USA). Standards and samples were assayed as duplicates, and interassay variations were within the range given by manufacture. Assay sensitivity was 1.0 $\mathrm{pg} / \mathrm{ml}$ for bFGF, $5.0 \mathrm{ng} / \mathrm{ml}$ for TGF $\beta 1$ and $1.953 \mathrm{ng} /$ $\mathrm{ml}$ for endostatin.

\section{Statistical analysis}

Comparisons of values were made with MannWhitney tests. Comparisons were considered significant when $p<0.05$. The linear correlations between serum cytokine levels as compared with the lymphocyte number were evaluated using the Sperman ranksum correlation method.

\section{Results}

The serum level of TGF $\beta 1$ and endostatin were measurable in all normal individuals and all CLL patients and bFGF was measurable in 24 out of 27 healthy volunteers and in all CLL patients.

The result of the measurements of TGF $\beta 1$, bFGF and endostatin are shown in Table 2.

The serum levels of both bFGF and TGF $\beta 1$ were found to be significantly higher in the CLL group (median $40.5 \mathrm{pg} / \mathrm{ml}$ and $38.6 \mathrm{ng} / \mathrm{ml}$, respectively) when compared to the control group (median $9.4 \mathrm{pg} /$ $\mathrm{ml}$ and $18.9 \mathrm{ng} / \mathrm{ml}$, respectively; $p<0.001$ ). The levels of endostatin were not significantly different between the control and the CLL group (median 8.4 $\mathrm{ng} / \mathrm{ml}$ and $12.3 \mathrm{ng} / \mathrm{ml}$, respectively; $p=0.09$ ). In the group of CLL patients the level of bFGF was significantly higher in patients with progressive disease as compared to patients with stable disease (median $90.5 \mathrm{pg} / \mathrm{ml}$ and $40.5 \mathrm{pg} / \mathrm{ml}$, respectively; $p=0.001)$. Patients in Rai stage III and IV also had significantly higher levels of bFGF than patients in Rai stage $0-$ II (median $100.1 \mathrm{pg} / \mathrm{ml}$ and $29.3 \mathrm{pg} / \mathrm{ml}$, respectively; $p<0.001)$. The levels of both TGF- $\beta 1$ and endostatin were lower in patients in Rai stage III and IV (median $28.9 \mathrm{ng} / \mathrm{ml}$ and $9.1 \mathrm{ng} / \mathrm{ml}$, respectively) than in patients in Rai stage 0-II $(42.8 \mathrm{ng} / \mathrm{ml}$ 
Table 2. Comparison of serum levels of TGF $\beta 1$, bFGF and endostatin in the healthy control group and in 80 untreated B-cell CLL patients

\begin{tabular}{|c|c|c|c|c|c|c|c|}
\hline Cytosine & $\begin{array}{c}\text { Control } \\
(n=27)(\mathrm{A})\end{array}$ & $\begin{array}{c}\text { All CLL } \\
\text { patients } \\
(n=80)(\mathrm{B})\end{array}$ & $\begin{array}{l}\text { Stable CLL } \\
(n=43)(C)\end{array}$ & $\begin{array}{l}\text { Progressive CLL } \\
\quad(n=37)(\mathrm{D})\end{array}$ & $\begin{array}{c}\text { Rai 0-II } \\
(n=52)(\mathrm{E})\end{array}$ & $\begin{array}{l}\text { Rai III-IV } \\
(n=28)(\mathrm{F})\end{array}$ & $\begin{array}{c}\text { Statistically } \\
\text { significant } \\
\text { comparison }\end{array}$ \\
\hline TGF-beta $(\mathrm{ng} / \mathrm{ml})$ & $\begin{array}{c}18.9 \\
(7.0-38.5)\end{array}$ & $\begin{array}{c}38.6 \\
(13.9-89.0)\end{array}$ & $\begin{array}{c}13.0 \\
(15.8-89.0)\end{array}$ & $\begin{array}{c}32.3 \\
(13.9-63.2)\end{array}$ & $\begin{array}{c}42.8 \\
(13.9-89.0)\end{array}$ & $\begin{array}{c}28.9 \\
(13.9-42.0)\end{array}$ & $\begin{array}{l}\text { A vs. } \mathrm{B}: p<0.001 \\
\mathrm{C} \text { vs. } \mathrm{D}: p<0.001 \\
\mathrm{E} \text { vs. } \mathrm{F}: p<0.001\end{array}$ \\
\hline $\begin{array}{l}\mathrm{bFGF} \\
(\mathrm{pg} / \mathrm{ml})\end{array}$ & $\begin{array}{c}9.4 \\
(0-20.1)\end{array}$ & $\begin{array}{c}40.5 \\
(5.1-230.5)\end{array}$ & $\begin{array}{c}41.9 \\
(5.1-150.0)\end{array}$ & $\begin{array}{c}90.5 \\
(10.1-230.5)\end{array}$ & $\begin{array}{c}29.3 \\
(5.1-150.0)\end{array}$ & $\begin{array}{c}100.1 \\
(10.1-230.5)\end{array}$ & $\begin{array}{l}\text { A vs. } \mathrm{B}: p<0.001 \\
\mathrm{C} \text { vs. } \mathrm{D}: p<0.001 \\
\mathrm{E} \text { vs. } \mathrm{F}: p<0.001\end{array}$ \\
\hline $\begin{array}{l}\text { Endostatin } \\
(\mathrm{ng} / \mathrm{ml})\end{array}$ & $\begin{array}{c}8.4 \\
(2.1-21.5)\end{array}$ & $\begin{array}{c}12.3 \\
(2.9-58.0)\end{array}$ & $\begin{array}{c}20.5 \\
(6.4-34.0)\end{array}$ & $\begin{array}{c}10.0 \\
(2.9-58.0)\end{array}$ & $\begin{array}{c}13.1 \\
(4.4-34.0)\end{array}$ & $\begin{array}{c}9.1 \\
(2.9-58.0)\end{array}$ & $\begin{array}{l}\text { A vs. B: } p=0.09 \\
\text { C vs. D: } p=0.008 \\
\text { E vs. F: } p=0.002\end{array}$ \\
\hline
\end{tabular}

and $13.1 \mathrm{ng} / \mathrm{ml}$, respectively; $p<0.001$ and $p=$ 0.002 , respectively). The level of endostatin was also lower in the group of CLL patients with progressive disease (median $10.0 \mathrm{ng} / \mathrm{ml}$ ) as compared to patients with stable disease (median $20.5 \mathrm{ng} / \mathrm{ml} ; p=0.008$ ).

In the entire group of CLL patients we have found a negative correlation between the serum level of TGF $\beta 1$ and bFGF $(p=0.019, R=-0.26)$ and the serum levels of endostatin and bFGF $(p=0.0004$, $R=0.39$ ). We have also found a positive correlation between the number of lymphocytes in the peripheral blood of CLL patients and the level of bFGF $(p<$ $0.0001, R=0.48)$ and endostatin $(p=0.0003, R=$ $0.39)$.

\section{Discussion}

The angiogenic switch in tumor cells is characterised at a molecular level by an imbalance in the production of pro- and anti-angiogenic factors. There is more and more evidence that B-CLL cells themselves may be an important source of these factors, but their exact role in the biology of the disease remains unclear. ${ }^{10,16}$ In order to determine if the levels of proand anti-angiogenic factors are associated with the course of the disease we compared the levels of bFGF, TGF $\beta 1$ and endostatin to the Rai risk stage and whether a patient has stable or progressive disease.

CLL cells-derived bFGF acts as a paracrine endothelial cells mitogen in angiogenesis. It enhances the proliferation of a variety of ectoderm- and mesoderm-derived cells, such as epithelial cells and fibroblasts. ${ }^{1}$ It also acts in an autocrine fashion on CLL cells behavior such as prolong survival due to inhibition of apoptosis. ${ }^{17}$ Thus, in progressive phase of CLL, when the lymphocytosis doubling time is quick and the expansion of lymphoid tissue and neovascularisation take place, bFGF could play an important role. Our investigations revealed significantly higher serum bFGF levels in CLL patients as compared to the healthy control group $(p<0.001)$. Furthermore we revealed that bFGF concentration is significantly higher in the serum of patients with more advanced Rai stage and in those with progressive disease $(p<0.001)$. We also observed the positive correlation between the serum level of this cytokine and the number of lymphocytes in the peripheral blood. These observations are in agreement with other studies. ${ }^{17,19}$ Most of the studies revealed a positive correlation between the increased bFGF concentrations and tumor progression or patient survival. High pre-treatment level of bFGF has been found an independent predictor of poor prognosis in non-Hodgkin lymphomas. ${ }^{19}$ Our previous study revealed that serum levels of bFGF and TGF $\beta 1$ were significantly higher in progressive CLL patients than in patients in complete remission. ${ }^{20}$ Menzel et al. revealed a high level of bFGF in lymphocytes of CLL patients, especially those with high-risk disease. ${ }^{17}$ Molica et al. analysed 81 Binet stage A CLL patients and found that serum levels of bFGF positively correlated with Rai sub-stages but failed to demonstrate any correlation between the bFGF level and disease progression. In contrast to our results they did not find correlation between bFGF concentration and peripheral blood lymphocytosis. $^{18}$

CLL-B cells were shown to express TGF $\beta 1$ RNA and to release bioactive TGF $\beta 1$ into culture supernatants. ${ }^{21}$ Autocrine secretion of TGF $\beta 1$ exibits an antiproliferative effect on CLL-B cells. This effect is most relevant in B cells cultured in direct contact with activated CD $4+\mathrm{T}$ cells suggesting an indirect mode of action. ${ }^{22}$ On the other hand TGF $\beta 1$ is a well known pro-angiogenic factor. ${ }^{23}$ It also has been shown to potentate the expression of VEGF, the most potent pro-angiogenic factor in CLL. ${ }^{24}$ In our studies we observed a significantly higher concentration of TGF $\beta 1$ in the serum of untreated CLL patients when compared to the control group $(p<0.001)$. An increased TGF $\beta 1$ level in comparison with healthy controls has been demonstrated in patients with renal, colorectal and nasopharyngeal carcinoma. ${ }^{25-27}$ There was also a correlation between high TGF $\beta 1$ serum level and advanced tumor stage. In contrast 
we observed significantly lower serum levels of this cytokine in patients with advanced CLL stages $(p<$ 0.001). It is not unexpected because although TGF $\beta 1$ is a molecule with pro-angiogenic activity it is also known as an autocrine growth inhibitor of lymphocyte proliferation. ${ }^{28}$ TGF $\beta 1$ appears to function in CLL as a negative regulator of $\mathrm{B}$ lymphocytes but loss of responsiveness to this cytokine accompanied by a decrease of TGF $\beta 1$ receptor expression, might provide a selective advantage to $\mathrm{B}$ CLL lymphocytes. ${ }^{29-31}$ Moreover this increased TGF $\beta 1$ production could be responsible for the inhibiting activity on hematopoietic precursors and bone marrow failure seen in advances stages of CLL. ${ }^{32}$

In addition to pro-angiogenic growth factors we evaluated plasma levels of endostatin an endogenous inhibitor of angiogenesis. ${ }^{3}$ However we did not find a difference between serum levels of this cytokine in CLL patients and the healthy control group $(p=0.09)$. Other authors have reported endostatin levels similar to healthy control in patients with squamous cell vulvar carcinoma and hepatocellular carcinoma. ${ }^{33,34}$ The same observation was made in patients with rheumatoid arthritis and systemic lupus erythematosus (SLE). ${ }^{35,36}$ In contrast Feldman et al. found significantly elevated serum levels of endostatin in the serum of patients with clear cell renal carcinoma and soft tissue sarcoma as compared to healthy control. ${ }^{37,38}$ It is worth noting that in our study, the serum endostatin levels were significantly lower in patients with advanced Rai stages or progressive disease as compared to lower Rai stages and stable disease $(p<0.001)$. We also found a positive correlation between the serum concentration of endostatin and peripheral blood lymphocytosis and a negative correlation between this cytokine level and bFGF serum concentration. Similar to our results, a negative correlation between endostatin and bFGF was also revealed in patients with SLE. ${ }^{36}$ In contrast Bertolini et al., in series of 36 non-Hodgkin lymphoma patients, did not find a difference in endostatin level between patients in complete remission and patients with progressive disease nor a correlation between endostatin levels and event-free survival rate. ${ }^{39}$ Feldman $e t$ al. revealed that higher endostatin levels were associated with an increased risk of tumour recurrence after resection of soft tissue sarcoma. ${ }^{37}$ They also found the positive correlation of endostatin and pro-angiogenic VEGF.

In conclusion, the results of the current study showed that the levels of anti-angiogenic endostatin and pro-apoptotic TGF $\beta 1$ are lower in the serum of CLL patients in advanced stages or with progressive disease while the level of pro-angiogenic bFGF is significantly higher in these groups of patients. The imbalance between these cytokines may have an influence on the course of the disease.
ACKNOWLEDGEMENTS. This study was supported in part by a grant from the Medical University of Lódz (No. 502-11-657(147)). The authors wish to thank Ms Jolanta Fryczak for technical assistance.

\section{References}

1. Tung-Ping Poon R, Fan ST, Wong J. Clinical implications of circulating angiogenic factors in cancer patients. J Clin Oncol 2001; 19: 1207-1225.

2. Bertolini F, Mancuso P, Gobbi A, Pruneri G. The thin red line angiogenesis in normal and malignant hematopoiesis. Exp Hematol 2000; 28: $993-1000$.

3. O'Reilly MS, Boehm T, Shing Y, et al. Endostatin: an endogenous inhibitor of angiogenesis and tumor growth. Cell 1997; 88: 277-285.

4. Padro T, Ruiz S, Bieker R, et al. Increased angiogenesis in the bone marrow of patients with acute leukemia. Blood 2000; 95: 2637-2644.

5. Perez Atayde AR, Sallan SE, Tedrow U, Connors S, Allred E, Folkman J. Spectrum of tumor angiogenesis in the bone marrow of children with acute lymphoblastic leukemia. Am J Pathol 1997; 150: 815-821.

6. Rajkumar SV, Fonseca R, Witzig TE, Gertz MA, Greipp PR. Bone marrow angiogenesis in patients achieving complete response after stem cell transplantation for multiple myeloma. Leukemia 1999; 13: 469-472.

7. Kini AR, Kay NE, Peterson LC. Increased bone marrow angiogenesis in B-cell chronic lymphocytic leukemia. Leukemia 2000; 14: 1414-1418.

8. Chen H, Treweeke AT, West DC, Till KJ, Cowley JC, Zuzel M. In vitro and in vivo production of vascular endothelial growth factor by chronic lymphocytic leukemia cells. Blood 2000; 96: 3181-3187.

9. Duensing S, Atzpodien J I. Increased intracellular and plasma levels of basic fibroblast growth factor in B-cell chronic lymphocytic leukemia. Blood 1995; 85: 1978-1980.

10. Kay NE, Bone ND, Tschumper RC, et al. B-CLL cells are capable of synthesis and secretion of both pro- and anti-angiogenic molecules. Leukemia 2002; 16: 911-919.

11. Kay NE, Jelinek DF, Peterson L. Angiogenesis in B-chronic lymphocytic leukemia. Leuk Res 2001; 25: 709-710.

12. Cheson BD, Bennett JM, Grever M, et al. National Cancer InstituteSponsored Working Group guidelines for chronic lymphocytic leukemia: revised guidelines for diagnosis and treatment. Blood 1996; 87: 4990- 4997.

13. Robak T, Blonski JZ, Kasznicki M, et al. Cladribine with prednisone versus chlorambucil with prednisone as first-line therapy in chronic lymphocytic leukemia: report of a prospective, randomized, multicenter trial. Blood 2000; 96: 2723-2729.

14. Rai KR, Sawitsky A, Cronkite EP, Chanana AD, Levy RN, Pasternack BS. Clinical staging of chronic lymphocytic leukemia. Blood 1975; 46: $219-$ 234

15. Rai KR. A critical analysis of staging in CLL. In: Gale RP, Rai KR, eds. Chronic lymphocytic leukemia. Recent progress and future direction, New York: Alan R. Liss S, 1987: 253-264.

16. Molica S. Angiogenesis in B-cell chronic lymphocytic leukemia: methods of study, clinical significance and prognostic implications. Leuk Lymph 2001; 42: 603-607.

17. Menzel T, Rahman Z, Calleja E, White K, Wilson EL, Wieder R, Gabrilove $\mathrm{J}$. Elevated Intracellular level of basic fibroblast growth factor correlates with stage of chronic lymphocytic leukemia and is associated with resistance to fludarabine. Blood 1996; 87: 1056-1063.

18. Molica S, Vitelli G, Levato D, Ricciotti A, Digiesi G. Clinicoprognostic implications of increased serum levels of vascular growth factor and basic fibroblast growth factor in early B-cell chronic lymphocytic leukemia. Br J Cancer 2002; 86: 31-35.

19. Salven P, Teerenhovi L, Joensuu H. A high pretreatment serum basic fibroblast growth factor concentration is an independent predictor of poor prognosis in non-Hodgkin's lymphoma. Blood 1999; 94: $3334-$ 3339

20. Gora-Tybor J, Blonski JZ, Robak T. Cladribine decreases the level of angiogenic factors in patients with chronic lymphocytic leukemia. Neoplasma 2002; 49: 145-148.

21. Kremer JP, Reisbach G, Nerl C, Dormer P. B-cell chronic lymphocytic leukaemia cells express and release transforming growth factor-beta. $\mathrm{Br}$ J Haematol 1992; 80: 480-487.

22. Schuler M, Tretter T, Schneller F, Huber C, Peschel C. Autocrine transforming growth factor beta from chronic lymphocytic leukemia-B cells interferes with proliferative T cell signals. Immunobiology 1999; 200: $128-139$.

23. Pepper MS. Transforming growth factor beta: vasculogenesis, angiogenesis, and vessel wall integrity. Cytokine Growth Factor Rev 1997; 8: $21-$ 43

24. Pertovaara L, Kaipainen A, Mustonen T, Orpano A, Ferrara N, Saksela O, Alitalo K. Vascular endothelial growth factor is induced in response to transforming growth factor beta in fibroblastic and epithelial cells. $J$ Biol Chem 1994; 269: 6271-6274.

25. Shim KS, Kim KH, Han WS, Park EB. Elevated serum level of transforming growth factor beta1 in patients with colorectal carcinoma: its association with tumor progression and its significant decrease after curative surgical resection. Cancer 1999; 84: 396-399. 
26. Wunderlich H, Steiner T, Junker U, Knofel B, Schlichter A, Schubert J Serum transforming growth factor beta1 in patients with renal cell carcinoma. J Urol 1997; 157: 1602-1603.

27. Xu J, Menezes J, Prasad U, Ahmad A. Elevated serum levels of transforming growth factor beta1 in Epstein-Barr virus-associated nosopharyngeal carcinoma patients. Int J Cancer 1999; 84: 396-399.

28. Lotz M, Ranheim E, Kipps TJ. Transforming growth factor beta as endogenous growth inhibitor of chronic lymphocytic leukemia B cells. $J$ Exp Med 1994; 179: 999-1004.

29. DeCoteau JF, Knaus PI, Yankelev H, Reis MD, Lowsky R, Lodish HF, Kadin ME. Loss of functional cell surface transforming growth factor beta (TGF-beta) type 1 receptor correlates with insensivity to TGF-beta in chronic lymphocytic leukemia. Proc Natl Acad Sci USA 1997; 94: $5877-$ 5881

30. Douglas RS, Capocasale RJ, Lamb RJ, Nowell PC, Moore JS. Chronic lymphocytic leukemia B cells are resistant to the apoptotic effects of transforming growth factor-beta. Blood 1997; 89: 941-947.

31. Lagneaux L, Delforge A, Bron D, Massy M, Bernier M, Stryckmans P. Heterogenous response of $\mathrm{B}$ lymphocytes to transforming growth factorbeta in B-cell chronic lymphocytic leukemia: correlation with the expression of TGF-beta receptors. Br J Haematol 1997; 97: 612-620.

32. Lagneaux L, Delforge A, Dorval C, Bron D, Stryckmans P. Excessive production of transforming growth factor- $\beta$ by bone marrow stromal cells in B-cell chronic lymphocytic leukemia inhibits growth of hematopoietic precursors and interleukin-6 production. Blood 1993; 82: $2379-2385$.
33. Hefler R, Tempfer C, Kainz C, Obermair A. Serum concentrations of endostatin in patients with vulvar cancer. Gynecol Oncol 1999; 74: 151152.

34. Yagamata M, Shiratori Y, Dan Y, Shiina S, Takayama T, Maruuchi M. Serum endostatin levels in patients with hepatocellular carcinoma. Ann Oncol 2000; 11: 761-762.

35. Nagashima N, Asano G, Yoshino S. Imbalance in production between vascular endothelial growth factor and endostatin in patients with rheumatoid arthritis. J Rheumatol 2000; 27: 2339-2342.

36. Robak E, Wozniacka A, Sysa-Jedrzejowska A, Stepien H, Robak T Circulating angiogenesis inhibitor endostatin and positive endothelial growth regulators in patients with systemic lupus erythematosus. Lupus 2002; 11: 348-355

37. Feldman AL, Pak H, Yang JC, Alexander HR, Libutti SK. Serum endostatin levels are elevated in patients with soft tissue sarcoma. Cancer 2001; 91: 1525-1529.

38. Feldman AL, Tamarkin L, Paciotti GF, et al. Serum endostatin levels are elevated and correlate with serum vascular endothelial growth factor levels in patients with stage IV clear cell renal cancer. Clin Cancer Res 2000; 6: 4628-4634

39. Bertolini F, Paolucci M, Peccatori F, et al. Angiogenic growth factors and endostatin in non-Hodgkin's lymphoma. Br J Haematol 1999; 106: 504509

\section{Received 19 March 2003}

Accepted 14 April 2003 


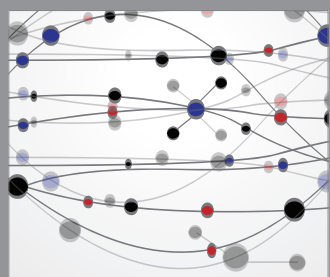

The Scientific World Journal
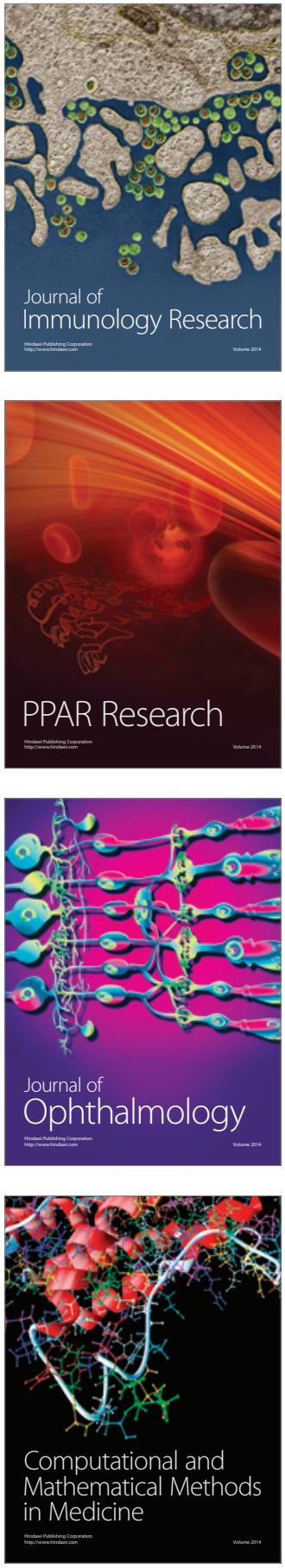

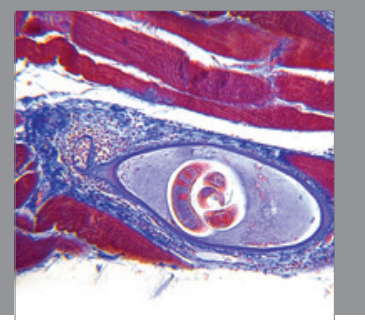

Gastroenterology

Research and Practice
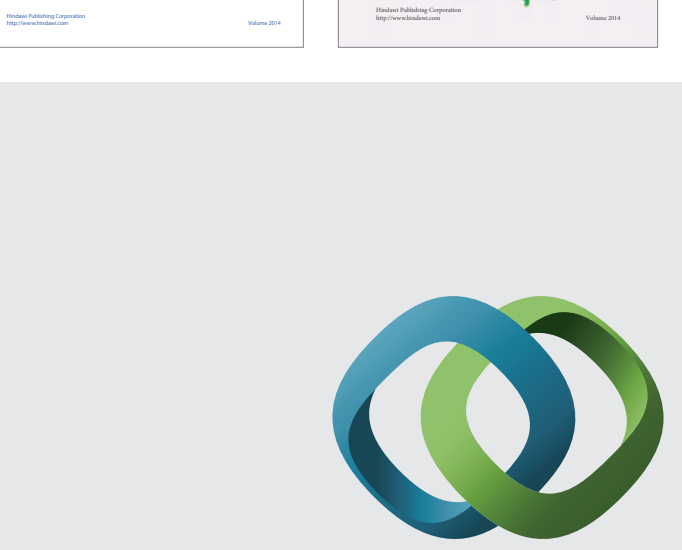

\section{Hindawi}

Submit your manuscripts at

http://www.hindawi.com
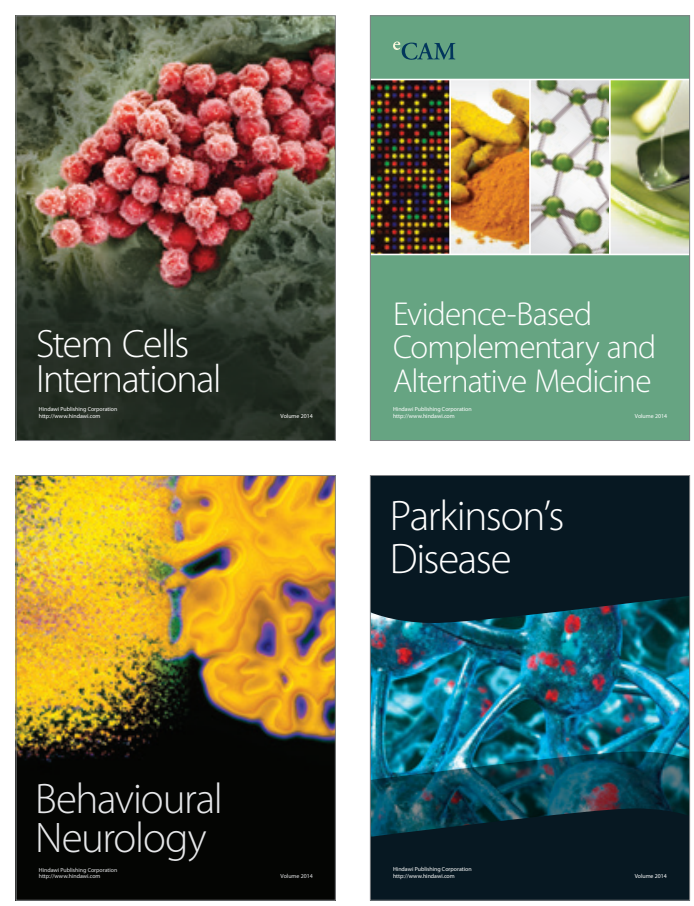

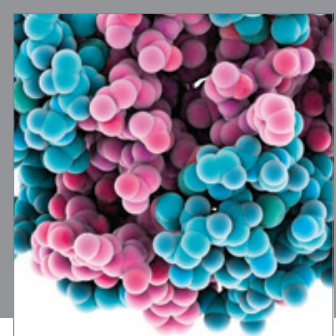

Journal of
Diabetes Research

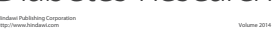

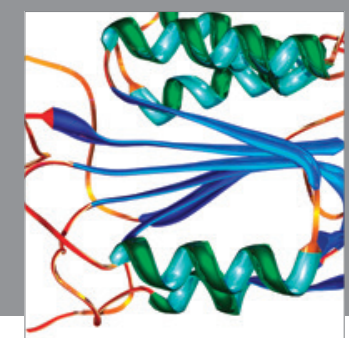

Disease Markers
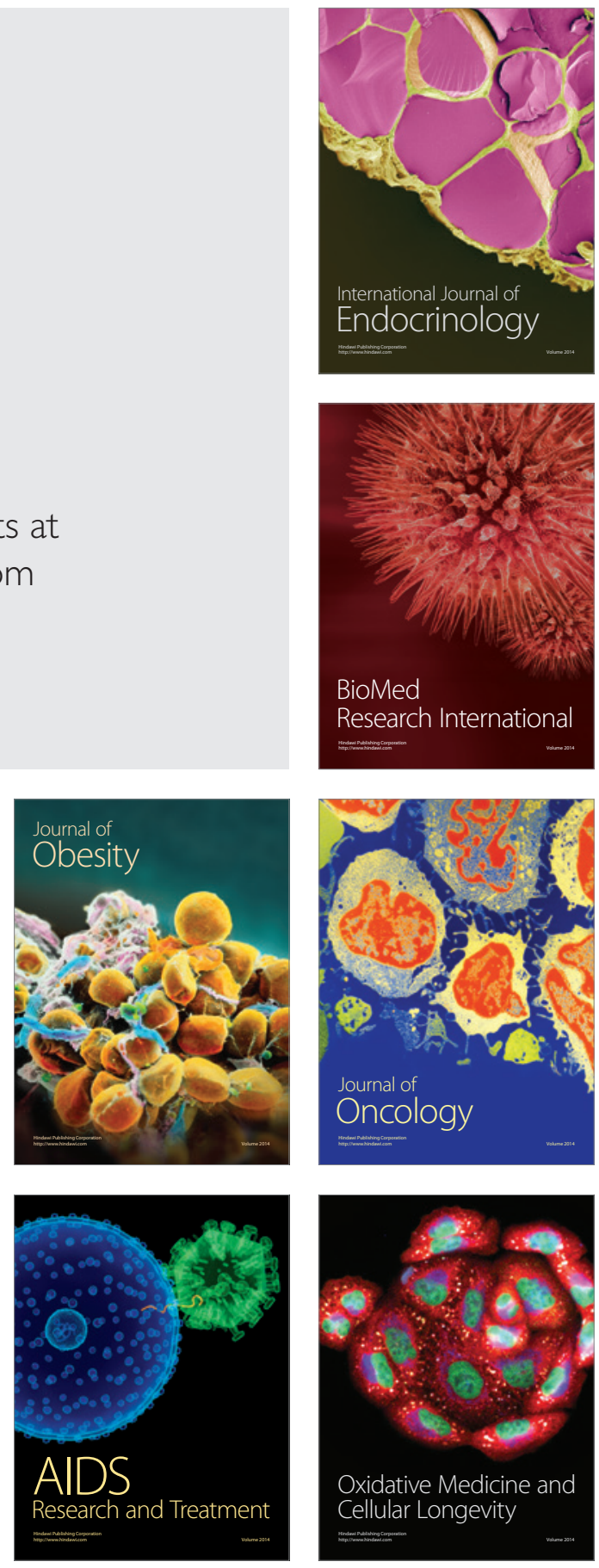